\title{
Keragaman Genetik Karakter Kuantitatif pada Tanaman Cabai (Capsicum annuum L.)
}

\section{Genetic Variability in Quantitative Traits of Chili (Capsicum annuum L.)}

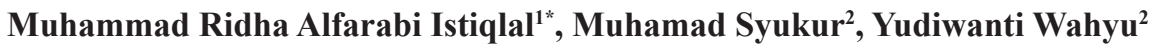 \\ ${ }^{1}$ Department of Agrotechnology, Faculty of Industrial Technology, Gunadarma University \\ ${ }^{2}$ Department of Agronomy and Horticulture, Faculty of Agricultural, IPB University
}

Diterima 22 Desember 2018/Disetujui 29 Januari 2019

\begin{abstract}
This study was to obtain genetic parameters information of quantitative traits in some chili genotypes that are related to yield traits using populations planted on two locations. Experimental design used was two factor randomized complete block design (RCBD) and three replications in two locations (Rimbo Panjang, Kampar and Leuwikopo, Bogor). Genetic variability was analyzed by cluster analysis. High broad sense heritability was observed from the traits. Cluster analysis by grouping 20 genotypes to 7 groups. The grouping was important to choose the parent lines for developing a new superior chili varieties with special fruit sizes.
\end{abstract}

Keywords: clustering analysis, genetic variabilty, similarity

\section{ABSTRAK}

Penelitian bertujuan untuk mendapatkan informasi parameter genetik karakter agronomi pada beberapa genotipe cabai yang berkaitan dengan karakter hasil menggunakan populasi yang ditanam pada dua lokasi. Percobaan dilakukan dengan menggunakan rancangan kelompok lengkap teracak (RKLT) dua faktor dengan tiga ulangan tersarang dalam lokasi (Rimbo Panjang, Kampar dan Leuwikopo, Bogor). Keragaman genetik dianalisis dengan analisis gerombol. Nilai heritabilitas arti luas setiap karakter yang diamati memiliki kriteria tinggi. Analisis gerombol yang dilakukan telah mengelompokkan 20 genotipe menjadi 7 kelompok. Pengelompokan ini dilakukan sebagai dasar pemilihan tetua dalam kegiatan pemuliaan yang akan dilakukan selanjutnya yaitu untuk merakit varietas cabai unggul baru dengan ukuran buah tertentu.

Kata kunci : analisis gerombol, kemiripan, variabilitas genetik

\section{PENDAHULUAN}

Tanaman cabai termasuk golongan sayuran yang dapat dimanfaatkan untuk banyak keperluan diantaranya untuk dikonsumsi segar dengan olahan sederhana, industri makanan dengan olahan sederhana dan olahan lanjut, bahan campuran obat-obatan dan industri pertahanan dan keamananan. Konsumsi cabai sangat tinggi secara nasional, yaitu mencapai $2.77 \mathrm{~kg} \mathrm{kapita}^{-1}$ tahun $^{-1}$ pada tahun 2011 (Kementerian Pertanian 2012). Berdasarkan data BPS (2011) produktivitas cabai nasional hanya mencapai 6.18 ton ha ${ }^{-1}$ pada tahun 2011 dan jauh di bawah potensinya, yaitu menurut Syukur et al. (2010) lebih dari 20 ton ha-1.

Alternatif usaha yang dapat dilakukan dalam rangka meningkatkan produktivitas cabai adalah dengan melakukan usaha intensifikasi, yaitu menanam varietas unggul berdaya hasil tinggi. Kegiatan pemuliaan tanaman dapat dilakukan untuk menghasilkan varietas unggul baru cabai dengan

\footnotetext{
* Penulis untuk korespondensi. e-mai : alfa.istiqlal@gmail.com
}

produktivitas tinggi (Orobiyi et al. 2013). Informasi keragaman genetik sangat mempengaruhi keberhasilan suatu kegiatan pemuliaan (Poehlman dan Sleeper, 1995). Sementara itu nilai heritabilitas diperlukan untuk melihat seberapa besar karakter yang diamati dikendalikan oleh faktor genetik (Geleta dan Labuschagne, 2006) dan dapat mengukur kemampuan suatu genotipe dalam populasi tanaman dalam mewariskan karakter yang dimilikinya (Roy, 2000). Karakter suatu individu tidak dapat dipastikan benar-benar terwariskan karena ekspresi visual (fenotipe) dipengaruhi oleh faktor genetik dan faktor lingkungan. Pengaruh lingkungan dapat dipisahkan dengan cara menanam bahan tanaman pada dua lokasi penanaman, sehingga akan menghasilkan kegaraman genetik yang telah terpisahkan dari pengaruh lingkungannya. Selanjutmya dalam pemilihan tanaman unggul secara visual dengan memilih fenotipe yang dianggap baik belum dapat memberikan hasil yang memuaskan tanpa berpedoman pada nilai-nilai parameter seleksi, seperti nilai heritabilitas, ragam genetik, ragam fenotipe dan koefisien keragaman genetik (KKG). Penelitian 
ini bertujuan mendapatkan informasi genetik dan heritabilitas karakter kuantitatif beberapa genotipe cabai menggunakan populasi yang ditanam di dua lokasi.

\section{BAHAN DAN METODE}

Penelitian dilaksanakan pada bulan Juli 2011 sampai dengan Januari 2012 di Kebun Rimbo Panjang, KamparRiau dan Kebun Leuwikopo, Bogor-Jawa Barat. Materi genetik yang digunakan adalah 20 genotipe cabai koleksi Laboratorium Pendidikan Pemuliaan Tanaman, Departemen Agronomi dan Hortikultura, Fakultas Pertanian IPB, yaitu C2, C5, C19, C18, C143, C157, F5110005-13-5, F5110005-13-12, F5120005-11-1, dan F5120005-12-1 (tipe cabai besar); C51, C105, C111, C117, C118, C120, C140, dan C159 (tipe cabai keriting); serta C145 dan C160 (tipe cabai rawit). Percobaan dilakukan dengan menggunakan rancangan kelompok lengkap teracak (RKLT) dua faktor dengan tiga ulangan. Ulangan tersarang dalam lokasi (Rimbo Panjang dan Leuwikopo). Faktor pertama 20 genotipe cabai dan faktor kedua adalah 2 lokasi percobaan. Setiap satuan percobaan terdiri atas 20 tanaman dengan 10 tanaman contoh. Data yang diperoleh dianalisis dengan analisis ragam gabungan menggunakan fasilitas SAS 9.0 Software.

Pelaksanaan percobaan diawali dengan kegiatan penyemaian benih sebanyak dua butir per lubang tray pada media semai steril. Pemupukan dilakukan setelah bibit berumur dua minggu setelah semai dengan periode satu minggu sekali menggunakan NPK Mutiara dengan dosis 10 $\mathrm{g} \mathrm{l}^{-1}$ air dan gandasil $2 \mathrm{~g} \mathrm{l}^{-1}$ air serta diaplikasikan dengan cara dikocor pada media semai.Pengolahan lahan dan pembuatan bedengan dilakukan bersamaan saat kegiatan penyemaian. Penanaman dilakukan setelah bibit cabai berumur 30 hari setelah semai. Petak bedengan dibuat dengan ukuran $1 \times 5$ $\mathrm{m}$ dengan jarak antar bedengan $50 \mathrm{~cm}$. Setiap bedengan diberi pupuk kandang sebanyak $20 \mathrm{~kg}$ dan kapur $0.5 \mathrm{~kg}$ serta dibera selama dua minggu, bedengan ditutup dengan mulsa plastik hitam perak (MPHP). Jarak tanam menggunakan ukuran 50x $50 \mathrm{~cm}$.Penyemprotan pestisidadilakukan dua minggu sekali dengan menggunakan fungisida berbahan aktif Mankozeb $\left(2 \mathrm{~g} \mathrm{~L}^{-1}\right)$ dan insektisida berbahan aktif Prefonofos $\left(2 \mathrm{~mL} \mathrm{~L}^{-1}\right)$.Kegiatan pemanenan dilakukan setiap minggu selama delapan minggu dengan kriteria buah cabai mencapai tingkat kematangan $75 \%$.

Pengamatan yang dilakukan pada percobaan mengacu pada Descriptors for Capsicum (IPGRI 1995) meliputi: umur berbunga (HST), jumlah hari setelah tanam sampai $50 \%$ populasi tanaman setiap bedengan berbunga, umur panen (HST), 50\% tanaman di dalam petak telah mempunyai buah masak pada percabangan pertama, tinggi tanaman (cm) diukur dari pangkal batang sampai titik tumbuh tertinggi, tinggi dikotomus $(\mathrm{cm})$ diukur dari pangkal batang sampai cabang dikotomus. Pengukuran tinggi tanaman dan dikotomus dilakukan pada panen kedua, lebar tajuk $(\mathrm{cm})$ diukur pada tajuk terlebar pada panen pertama, panjang buah $(\mathrm{cm})$, panjang tangkai buah $(\mathrm{cm})$, diameter buah $(\mathrm{mm})$, bobot buah $(\mathrm{g})$, panjang buah diambil rata-rata 10 buah setiap ulangan pada panen kedua hingga keempat, bobot buah diambil rata-rata 10 buah setiap ulangan pada panen kedua hingga keempat dan diukur menggunakan timbangan analitik, jumlah buah total per tanaman yang dihitung dengan menjumlahkan total buah tiap panen selama 8 minggu dan dibagi dengan jumlah tanaman sampel dan bobot buah total per tanaman $\left(\mathrm{g} \mathrm{tan}^{-1}\right)$, dihitung dengan menjumlahkan bobot buah tiap panen selama 8 minggu dan dibagi dengan jumlah tanaman sampel.

\section{Analisis Data}

Perbedaan antar genotipe diuji menggunakan uji F pada taraf nyata 5\%, dilakukan uji lanjut Duncan's New Multiple Range Test (DNMRT) taraf 5\% dan diduga parameter genetiknya. Pendugaan parameter genetik meliputi pendugaan ragam genetik $\left(\sigma_{\mathrm{g}}^{2}\right)$, ragam interaksi genetik $\mathrm{x}$ lingkungan $\left(\sigma_{\text {gxe }}^{2}\right)$, ragam lingkungan $\left(\sigma_{\mathrm{e}}^{2}\right)$, ragam fenotipe $\left(\sigma_{\mathrm{p}}^{2}\right)$ (Hallauer dan Miranda 1995) dan nilai koefisien keragaman genetik (KKG).Keragaman genetik suatu karakter ditentukan berdasarkan ragam genetik dan standar deviasi ragam genetik (Pinaria et al. 1995). Nilai dugaan heritabilitas $\left(\mathrm{h}^{2}\right)$ dalam arti luas (Poespodarsono, 1988). Nilai heritabilitas diklasifikasikan rendah, sedang dan tinggi menurut Elrod dan Stansfield (2002). Keragaman genetik dan pola hubungan kekerabatan dianalisis dengan analisis gerombol (cluster analysis) menggunakan software SPSS versi 20. Informasi hubungan kekerabatan digunakan sebagai dasar dalam rekomendasi tetua yang akan dipilih pada pembentukan populasi studi pewarisan. Jika terdapat beberapa genotipe calon tetua, akan dipilih genotipe yang lebih ekstrim, hubungan genetik yang lebih jauh, serta lebih mudah persilangannya.

\section{HASIL DAN PEMBAHASAN}

Analisis ragam gabungan untuk 20 genotipe tanaman cabai pada dua lokasi menunjukkan bahwa umumnya genetik, lokasi dan interaksinya berpengaruh sangat nyata pada karakter yang diamati, kecuali umur panen, tinggi tanaman dan jumlah buah per tanaman (Tabel 1 dan 2). Kondisi ini menunjukkan bahwa penampilan karakter yang diamati dipengaruhi oleh faktor genetik, lokasi dan interaksi antara genetik dan lingkungan.

Pengujian pada dua lokasi penanaman yang dilakukan pada 20 genotipe cabai bertujuan untuk menduga nilai pengaruh interaksi genetik lingkungan. Gambar 1 menunjukkan bahwa terdapat respon yang berbeda pada penampilan karakter bobot buah per tanaman. Umumnya penampilan karakter bobot buah per tanaman pada lokasi penanaman di Rimbo Panjang memperlihatkan respon yang lebih baik daripada lokasi penanaman Leuwikopo, kecuali genotipe C140.

Selain untuk melihat interaksi genetik lingkungan, penanaman pada dua lokasi dilakukan agar pengaruh genetik yang didapat telah bebas dari pengaruh interaksi genetik dan lingkungannya (Syukur et al. 2012). Selain itu penggunaaan model acak dalam perhitungan analisis ragam 
gabungan dilakukan untuk keperluan pendugaan ragam genetik dan menduga nilai-nilai parameter genetik yang berguna untuk program pemuliaan lanjutan dalam kegiatan seleksi pemilihan tetua yang tepat.

Nilai tengah karakter non buah dari 20 genotipe tanaman cabai pada penanaman dua lokasi disajikan pada Tabel 3. Nilai tengah umur berbunga pada 20 genotipe cabai yang ditanaman pada dua lokasi penanaman adalah 51.43 hari setelah tanam (HST). Genotipe C5 merupakan tanaman cabai yang berbunga terlebih dahulu dari pada genotipe lainnya, yaitu pada 31 HST. Genotipe C18 dan C19 merupakan tanaman cabai yang berbunga paling lama, yaitu pada 62 HST dan 61 HST (Tabel 3).

Nilai tengah umur panen pada 20 genotipe cabai yang ditanam pada dua lokasi penanaman adalah 92 HST. Genotipe yang memiliki nilai tengah umur panen genjah adalah genotipe C2, yaitu 89 HST. genotipe C120 adalah tanaman cabai yang memiliki nilai tengah umur panen paling lama, yaitu 99 HST. Hal ini dikarenakan genotipe C120 merupakan tipe cabai keriting. Genotipe C159 dan F5110005-13-12 merupakan tanaman cabai yang tertinggi, dikarenakan memiliki nilai tengah tinggi tanaman mencapai

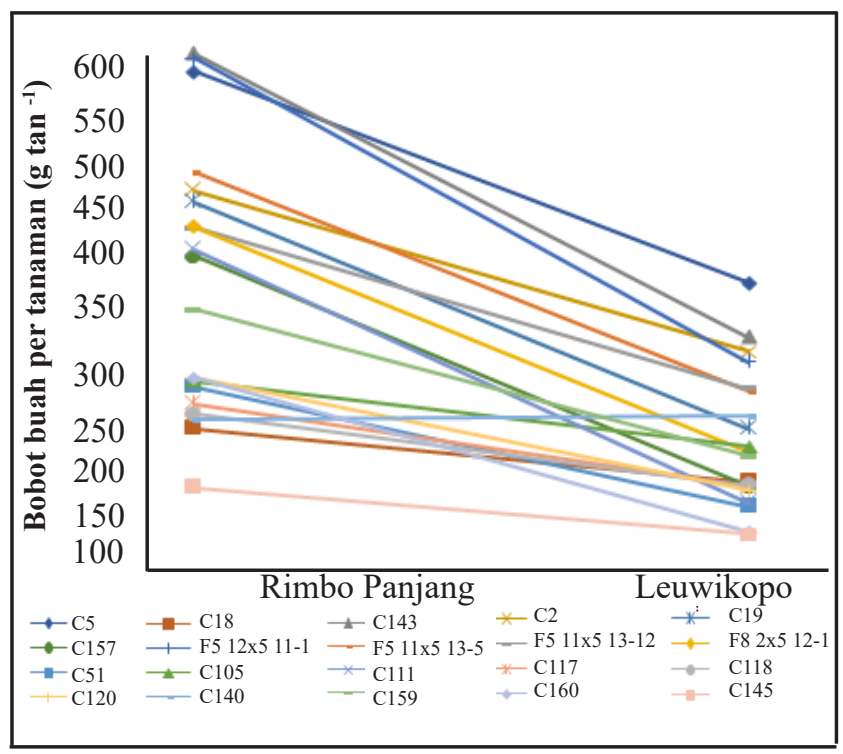

Gambar 1. Grafik interaksi genetik lingkungan pada karakter bobot buah per tanaman
$77.09 \mathrm{~cm}$ dan $78.13 \mathrm{~cm}$. Genotipe C157 merupakan genotipe yamg memiliki nilai tengah tinggi dikotomus tertinggi yaitu $34.85 \mathrm{~cm}$. Genotipe C18 merupakan tipe tanaman pendek karena memiliki nilai tengah tinggi tanaman dan tinggi dikotomus kurang dari 0.5 meter, yaitu $45.15 \mathrm{~cm}$ dan 21.31 $\mathrm{cm}$. Kisaran lebar tajuk dari 20 genotipe yang ditanaman antara $69.37 \mathrm{~cm}$ (C140) hingga $95.11 \mathrm{~cm}$ (C120).

Karakter buah yang diamati pada populasi ini mencakup panjang buah, panjang tangkai buah, diameter buah, bobot per buah, jumlah buah pertanaman dan bobot buah pertanaman (Tabel 4). Genotipe C120 merupakan tanaman cabai yang memilikibuah terpanjang, yaitu 19.20 $\mathrm{cm}$. Sementara itu genotipe C160 merupakan tipe cabai rawit yang memiliki panjang buah hanya $3.88 \mathrm{~cm}$. Karakter panjang tangkai buah pada 20 genotipe yang diamati memiliki nilai tengah $4.38 \mathrm{~cm}$, dalam rentang antara $3.29-5.71 \mathrm{~cm}$. Diameter buah pada populasi yang diamati memiliki kisaran antar 6.79-18.96 cm. Jauhnya rentang diameter buah yang diamati dikarenakan genotipe cabai yang digunakan berasal dari tipe cabai rawit hingga cabai besar. Hal ini juga terlihat pada karakter bobot per buah yang memiliki rentang antara $1.16 \mathrm{~cm}$ hingga $16.61 \mathrm{~cm}$.

Program pemuliaan tanaman bertujuan untuk menghasilkan tanaman unggul. Tanaman unggul umumnya diarahkan pada produktivitas yang tinggi juga. Pada tanaman cabai, jumlah buah yang banyak dan bobot buah pertanaman yang tinggi sangat diharapkan. Kondisi yang berbeda dapat dilihat dari data pada Tabel 4. Genotipe C5 merupakan tanaman yang memiliki nilai tengah bobot buah per tanaman yang tinggi, tetapi memiliki jumlah buah yang tidak termasuk pada kategori terbanyak. Sebaliknya genotipe C145 merupakan tanaman yang memiliki bobot buah per tanaman dalam terendah, yaitu $165.58 \mathrm{~g} \mathrm{tanaman}^{-1}$, tetapi genotipe ini memiliki jumlah buah per tanaman yang terbanyak,yaitu 160 buah tanaman ${ }^{-1}$. Oleh karena itu, program pemuliaan diperlukan untuk menghasilkan tanaman cabai unggul baru dengan jumlah dan ukuran buah tertentu.

Komponen ragam dari setiap karakter yang diamati disajikan pada Tabel 5. Pada Tabel 5 terdapat komponen ragam interaksi genotipe $\times$ lingkungan, informasi ini membuat pendugaan ragam genetik pada populasi ini akan lebih baik jika dibandingkan dengan penanaman populasi hanya pada satu lokasi (Syukur et al.2012). Menurut Baihaki (2000), informasi ragam genetik akan lebih baik

Tabel 1. Kuadrat tengah analisis ragam gabungan 20 genotipe karakter non buah tanaman cabai pada dua lokasi

\begin{tabular}{lrcrrrr}
\hline \multirow{2}{*}{ Sumber } & $\mathrm{db}$ & \multicolumn{3}{c}{ Kuadrat tengah } \\
\cline { 3 - 7 } & 1 & Umur berbunga & Umur panen & Tinggi tanaman & Tinggi dikotomus & Lebar tajuk \\
\hline Lokasi & $14322.67^{* *}$ & $8619.08^{* *}$ & $2067.52 \mathrm{tn}$ & $1299.31^{* *}$ & $13159.49^{* *}$ \\
Ulangan/Lokasi & 4 & $41.20 \mathrm{tn}$ & $5.24 \mathrm{tn}$ & $329.98^{* *}$ & $45.60^{* *}$ & $136.27^{* *}$ \\
Genotipe & 19 & $290.52^{* *}$ & $23.52^{* *}$ & $604.63^{* *}$ & $91.73^{* *}$ & $334.65^{* *}$ \\
Genotipe*Lokasi & 19 & $107.24^{* *}$ & $0.92 \mathrm{tn}$ & $239.00^{* *}$ & $22.88^{* *}$ & $100.78^{* *}$ \\
Galat & 76 & $23.58^{* *}$ & $2.15 \mathrm{tn}$ & $93.39 \mathrm{tn}$ & $9.29 \mathrm{t} \mathrm{n}$ & $37.48 \mathrm{t} \mathrm{n}$ \\
\hline
\end{tabular}

Keterangan: $*=$ berpengaruh nyata pada $\alpha=5 \%, * *=$ berpengaruh nyata pada $\alpha=1 \%, \operatorname{tn}=$ tidak nyata 
lagi jika populasi ditanampada minimal dua lokasi dan dua musim, sehingga interaksi genotipe $\times$ lingkungan, genotipe $\times$ musim, dan genotipe $\times$ musim $\times$ lingkungan dapat dipisahkan. Kondisi ini memungkinkan dugaan ragam genetik murni dari pengaruh interaksi lingkungannya, baik itu lokasi ataupun musim penanaman.

Tabel 2. Kuadrat tengah analisis ragam gabungan 20 genotipe karakter buah tanaman cabai pada dua lokasi

\begin{tabular}{lccccccc}
\hline & & \multicolumn{6}{c}{ Kuadrat tengah } \\
\cline { 3 - 8 } Sumber Keragaman & db & $\begin{array}{c}\text { Panjang } \\
\text { buah }\end{array}$ & $\begin{array}{c}\text { Panjang } \\
\text { tangkai buah }\end{array}$ & $\begin{array}{c}\text { Diameter } \\
\text { buah }\end{array}$ & $\begin{array}{c}\text { Bobot per } \\
\text { buah }\end{array}$ & $\begin{array}{c}\text { Jumlah buah per } \\
\text { tanaman }\end{array}$ & $\begin{array}{c}\text { Bobot buah per } \\
\text { tanaman }\end{array}$ \\
\hline Lokasi & 1 & $250.31^{* *}$ & $12.88^{* *}$ & $167.76^{* *}$ & $65.94^{* *}$ & $9555.05 \mathrm{tn}$ & $616787.93^{* *}$ \\
Ulangan/Lokasi & 4 & $7.33 \mathrm{tn}$ & $0.61 \mathrm{tn}$ & $10.24^{* *}$ & $2.22 \mathrm{tn}$ & $1399.42^{* *}$ & $6814.37 \mathrm{tn}$ \\
Genotipe & 19 & $65.17^{* *}$ & $3.02^{* *}$ & $80.89^{* *}$ & $76.01^{* *}$ & $8296.82^{* *}$ & $47429.16^{* *}$ \\
Genotipe*Lokasi & 19 & $10.41^{* *}$ & $0.66^{* *}$ & $14.46^{* *}$ & $5.31^{* *}$ & $407.54 \mathrm{tn}$ & $9409.33^{* *}$ \\
Galat & 76 & $3.70 \mathrm{tn}$ & $0.28 \mathrm{tn}$ & $3.46 \mathrm{tn}$ & $1.68 \mathrm{tn}$ & $373.47 \mathrm{tn}$ & $3943.45 \mathrm{tn}$ \\
\hline
\end{tabular}

Keterangan: *=berpengaruh nyata pada $\alpha=5 \%, * *=$ berpengaruh nyata pada $\alpha=1 \%$, tn=tidak nyata

Tabel 3. Nilai tengah 20 genotipe karakter non buah tanaman cabai pada dua lokasi

\begin{tabular}{|c|c|c|c|c|c|}
\hline Genotipe & $\begin{array}{c}\text { Umur berbunga } \\
(\mathrm{HST})\end{array}$ & $\begin{array}{c}\text { Umur panen } \\
\text { (HST) }\end{array}$ & $\begin{array}{l}\text { Tinggi tanaman } \\
(\mathrm{cm})\end{array}$ & $\begin{array}{l}\text { Tinggi dikotomus } \\
(\mathrm{cm})\end{array}$ & $\begin{array}{c}\text { Lebar tajuk } \\
(\mathrm{cm})\end{array}$ \\
\hline $\mathrm{C} 2$ & $41.00^{\mathrm{cd}}$ & $89.67^{i}$ & $48.04^{\mathrm{cd}}$ & $22.50^{\mathrm{fgh}}$ & $70.60^{\text {ef }}$ \\
\hline $\mathrm{C} 5$ & $31.83^{\mathrm{d}}$ & $90.67^{\text {ghi }}$ & $69.59^{\mathrm{abc}}$ & $27.67^{\mathrm{b}-\mathrm{h}}$ & $77.01^{\mathrm{c}-\mathrm{f}}$ \\
\hline $\mathrm{C} 18$ & $62.17^{a}$ & $92.50^{\mathrm{b}-\mathrm{e}}$ & $45.15^{\mathrm{d}}$ & $21.31^{\mathrm{h}}$ & $70.54^{\mathrm{ef}}$ \\
\hline C19 & $61.33^{\mathrm{a}}$ & $90.00^{\mathrm{i}}$ & $63.30^{\mathrm{a}-\mathrm{d}}$ & $29.06^{\mathrm{a}-\mathrm{f}}$ & $80.61^{\mathrm{b}-\mathrm{f}}$ \\
\hline $\mathrm{C} 51$ & $49.67^{\mathrm{abc}}$ & $92.50^{\mathrm{b}-\mathrm{e}}$ & $70.58^{\mathrm{ab}}$ & $28.18^{\mathrm{b}-\mathrm{g}}$ & $83.87^{\mathrm{a}-\mathrm{e}}$ \\
\hline $\mathrm{C} 105$ & $51.00^{\mathrm{abc}}$ & $92.00^{\mathrm{b}-\mathrm{f}}$ & $75.64^{\mathrm{ab}}$ & $29.68^{\mathrm{a}-\mathrm{e}}$ & $91.56^{\mathrm{ab}}$ \\
\hline C111 & $58.33^{\mathrm{ab}}$ & $92.83^{\text {bcd }}$ & $65.01^{\mathrm{a}-\mathrm{d}}$ & $31.28^{\mathrm{abc}}$ & $85.18^{\mathrm{a}-\mathrm{d}}$ \\
\hline C117 & $55.33^{\mathrm{abc}}$ & $92.17^{\text {bee }}$ & $71.56^{\mathrm{ab}}$ & $32.18^{\mathrm{abc}}$ & $83.56^{\mathrm{a}-\mathrm{e}}$ \\
\hline $\mathrm{C} 118$ & $50.33^{\mathrm{abc}}$ & $92.67^{\mathrm{be}}$ & $71.09^{\mathrm{ab}}$ & $31.00^{\mathrm{a}-\mathrm{d}}$ & $87.13^{\mathrm{a}-\mathrm{d}}$ \\
\hline $\mathrm{C} 120$ & $54.67^{\mathrm{abc}}$ & $99.33^{\mathrm{a}}$ & $75.05^{\mathrm{ab}}$ & $27.88^{\mathrm{b}-\mathrm{h}}$ & $95.11^{\mathrm{a}}$ \\
\hline C140 & $56.50^{\mathrm{ab}}$ & $92.00^{\mathrm{b}-\mathrm{f}}$ & $58.86^{\mathrm{a}-\mathrm{d}}$ & $24.41^{\mathrm{chh}}$ & $69.37^{\mathrm{f}}$ \\
\hline C143 & $48.00^{\mathrm{abc}}$ & $93.00^{\mathrm{bc}}$ & $62.58^{\mathrm{a}-\mathrm{d}}$ & $31.68^{\mathrm{abc}}$ & $88.04^{\mathrm{abc}}$ \\
\hline C145 & $51.50^{\mathrm{abc}}$ & $91.67^{\mathrm{c}-\mathrm{g}}$ & $47.22^{\mathrm{d}}$ & $25.70^{\mathrm{chh}}$ & $73.07^{\mathrm{def}}$ \\
\hline $\mathrm{C} 157$ & $56.00^{\mathrm{ab}}$ & $93.33^{\mathrm{b}}$ & $69.65^{\mathrm{abc}}$ & $34.85^{a}$ & $83.52^{\mathrm{a}-\mathrm{e}}$ \\
\hline C159 & $48.67^{\mathrm{abc}}$ & $91.50^{\mathrm{d}-\mathrm{h}}$ & $77.09^{a}$ & $32.62^{\mathrm{ab}}$ & $86.60^{\mathrm{a}-\mathrm{d}}$ \\
\hline $\mathrm{C} 160$ & $53.00^{\mathrm{abc}}$ & $92.00^{\mathrm{b}-\mathrm{f}}$ & $54.57^{\mathrm{bcd}}$ & $26.23^{\mathrm{b}-\mathrm{h}}$ & $73.14^{\mathrm{def}}$ \\
\hline F5110005-13-5 & $48.00^{\mathrm{abc}}$ & $91.33^{\mathrm{e}-\mathrm{h}}$ & $56.39^{\mathrm{a}-\mathrm{d}}$ & $22.29^{\mathrm{gh}}$ & $74.74^{\mathrm{c}-\mathrm{f}}$ \\
\hline F5110005-13-12 & $45.67^{\mathrm{bc}}$ & $90.33^{\text {hi }}$ & $78.13^{a}$ & $24.23^{\mathrm{e}-\mathrm{h}}$ & $78.52^{\mathrm{b}-\mathrm{f}}$ \\
\hline F5120005-11-1 & $55.83^{\mathrm{ab}}$ & $90.83^{f-i}$ & $62.19^{a-d}$ & $24.22^{\mathrm{e}-\mathrm{h}}$ & $73.38^{\text {def }}$ \\
\hline F8002005-12-1 & $49.67^{\mathrm{abc}}$ & $91.50^{\mathrm{d}-\mathrm{h}}$ & $62.77^{\mathrm{a}-\mathrm{d}}$ & $24.28^{\mathrm{e}-\mathrm{h}}$ & $78.07^{\mathrm{b}-\mathrm{f}}$ \\
\hline
\end{tabular}

Keterangan : Angka yang diikuti huruf yang sama pada kolom yang sama tidak berbeda nyata menurut DNMRT taraf 5\% 
Pendugaan nilai heritabilitas arti luas $\left(\mathrm{h}^{2}{ }_{\text {bs }}\right)$ pada setiap karakter yang diamati termasuk dalam kategori tinggi (Tabel 5). Hal ini menunjukkan bahwa keragaan karakter yang diamati lebih dipengaruhi oleh faktor genetik (Geleta dan Labuschagne, 2006) dan memiliki peluang yang besar untuk dapat terwariskan kepada zuriatnya. Penelitian cabai sebelumnya juga menunjukkan nilai heritabilitas arti luas yang tinggi pada karakter bobot buah per tanaman (Marame et al., 2008), bobot per buah (Mishra et al., 2004), panjang buah (Sreelathakumary dan Rajamony, 2004), dan diameter buah (Tembhume dan Rao, 2012). Selain itu nilai heritabilitas yang tinggi pada suatu karakter menjadi salah satu syarat pemilihan penanda atau kriteria seleksi dalam suatu program pemuliaan tanaman.

Salah satu kunci keberhasilan dari suatu program pemuliaan tanaman dalam rangka menghasilkan varietas unggul baru adalah pemilihan tetua yang tepat. Pemilihan tetua yang memiliki tingkat keragaman yang besar akan mempermudah pemulia untuk mendapatkan informasi mengenai pewarisan sifat untuk karakter penting pada suatu tanaman. Umumnya karakter yang diamati pada 20 genotipe tanaman cabai yang digunakan memiliki tingkat keragaman genetik yang tinggi (Tabel 5). Analisis gerombol merupakan salah satu analisis yang dapat mengelompokkan objek perlakuan berdasarkan setiap data pengamatannya ke dalam beberapa kelas (gerombol), sehingga setiap kelas terdiri dari objek perlakuan yang lebih homogen atau mirip (Yunianti et al., 2007). Pengelompokan ini didasarkan pada ukuran kemiripan menggunakan sebuah indeks dengan makna tertentu seperti jarak euclidean (akar ciri) atau jarak lain, sejenis indeks peluang, atau yang lainnya. Jarak akar ciri antar objek perlakuan akan menentukan kemiripan dari setiap objek perlakuan (Mattjik dan Sumertajaya, 2011).

Percobaan ini menggunakan 20 genotipe cabai (objek perlakuan) dengan 11 karakter yang diamati (data pengamatan) menghasilkan dendrogram dengan 7 kelompok

Tabel 4. Nilai tengah 20 genotipe karakter buah tanaman cabai pada dua lokasi

\begin{tabular}{|c|c|c|c|c|c|c|}
\hline Genotipe & $\begin{array}{l}\text { Panjang buah } \\
(\mathrm{cm})\end{array}$ & $\begin{array}{c}\text { Panjang tangkai } \\
\text { buah }(\mathrm{cm})\end{array}$ & $\begin{array}{c}\text { Diameter } \\
\text { buah }(\mathrm{mm})\end{array}$ & $\begin{array}{l}\text { Bobot per } \\
\text { buah }(\mathrm{g})\end{array}$ & $\begin{array}{l}\text { Jumlah buah } \\
\text { per tanaman }\end{array}$ & $\begin{array}{c}\text { Bobot buah per } \\
\text { tanaman }(\mathrm{g})\end{array}$ \\
\hline $\mathrm{C} 2$ & $13.81^{b c}$ & $3.95^{\mathrm{def}}$ & $14.26^{\mathrm{a}-\mathrm{d}}$ & $7.58^{\mathrm{bcd}}$ & $61.91^{\mathrm{efg}}$ & $385.73^{\mathrm{abc}}$ \\
\hline $\mathrm{C} 5$ & $10.46^{\text {bcd }}$ & $4.46^{\mathrm{b}-\mathrm{e}}$ & $18.96^{\mathrm{a}}$ & $9.69^{b}$ & $53.64^{\mathrm{fg}}$ & $471.49^{a}$ \\
\hline C18 & $11.66^{\mathrm{bcd}}$ & $3.28^{\mathrm{f}}$ & $16.16^{\mathrm{ab}}$ & $7.67^{\mathrm{bcd}}$ & $35.70^{\mathrm{g}}$ & $216.65^{\mathrm{de}}$ \\
\hline C19 & $12.26^{\mathrm{bcd}}$ & $4.02^{\mathrm{def}}$ & $15.93^{\mathrm{ab}}$ & $7.95^{\mathrm{bcd}}$ & $43.19^{\mathrm{g}}$ & $345.34^{\mathrm{a}-\mathrm{d}}$ \\
\hline C51 & $11.68^{\mathrm{bcd}}$ & $4.10^{\mathrm{def}}$ & $12.51^{\mathrm{b}-\mathrm{e}}$ & $2.97^{\mathrm{fgh}}$ & $84.51^{\mathrm{b}-\mathrm{e}}$ & $224.75^{\mathrm{de}}$ \\
\hline $\mathrm{C} 105$ & $18.98^{\mathrm{a}}$ & $5.71^{\mathrm{a}}$ & $9.75^{\mathrm{c}-\mathrm{f}}$ & $5.48^{\mathrm{c}-\mathrm{f}}$ & $52.34^{\mathrm{fg}}$ & $254.82^{\text {cde }}$ \\
\hline C111 & $11.02^{\mathrm{bcd}}$ & $3.66^{\mathrm{ef}}$ & $6.79^{f}$ & $2.95^{\mathrm{fgh}}$ & $110.36^{b}$ & $289.01^{\text {cde }}$ \\
\hline $\mathrm{C} 117$ & $11.56^{\mathrm{bcd}}$ & $4.22^{\mathrm{c}-\mathrm{f}}$ & $7.54^{\mathrm{ef}}$ & $4.04^{\mathrm{fgh}}$ & $91.49^{\mathrm{bcd}}$ & $226.02^{\mathrm{de}}$ \\
\hline C118 & $11.75^{\mathrm{bcd}}$ & $5.27^{\mathrm{abc}}$ & $10.46^{\mathrm{c}-\mathrm{f}}$ & $3.15^{\mathrm{fgh}}$ & $101.24^{\mathrm{bc}}$ & $221.34^{\mathrm{de}}$ \\
\hline C120 & $19.20^{\mathrm{a}}$ & $5.08^{\mathrm{a}-\mathrm{d}}$ & $7.74^{\mathrm{ef}}$ & $4.41^{\mathrm{efg}}$ & $71.02^{\mathrm{def}}$ & $235.85^{\text {de }}$ \\
\hline $\mathrm{C} 140$ & $9.65^{\mathrm{cd}}$ & $4.31^{\mathrm{b}-\mathrm{f}}$ & $10.05^{\mathrm{c}-\mathrm{f}}$ & $3.11^{\mathrm{fgh}}$ & $78.58^{\mathrm{c}-\mathrm{f}}$ & $250.88^{\text {cde }}$ \\
\hline C143 & $13.88^{\mathrm{bc}}$ & $5.36^{\mathrm{ab}}$ & $16.78^{\mathrm{ab}}$ & $16.61^{\mathrm{a}}$ & $37.73^{\mathrm{g}}$ & $454.97^{\mathrm{ab}}$ \\
\hline $\mathrm{C} 145$ & $8.42^{\mathrm{d}}$ & $3.29^{\mathrm{f}}$ & $9.12^{\mathrm{c}-\mathrm{f}}$ & $1.16^{\mathrm{h}}$ & $160.18^{a}$ & $165.58^{\mathrm{e}}$ \\
\hline C157 & $12.24^{\mathrm{bcd}}$ & $4.70^{\mathrm{a}-\mathrm{e}}$ & $8.50^{\text {ef }}$ & $3.35^{\mathrm{fgh}}$ & $108.08^{b}$ & $293.59^{\text {cde }}$ \\
\hline $\mathrm{C} 159$ & $12.66^{\mathrm{bcd}}$ & $4.00^{\text {def }}$ & $7.58^{\mathrm{ef}}$ & $3.07^{\mathrm{fgh}}$ & $98.21^{\mathrm{bcd}}$ & $282.95^{\text {cde }}$ \\
\hline $\mathrm{C} 160$ & $3.88^{\mathrm{e}}$ & $3.31^{\mathrm{f}}$ & $6.95^{f}$ & $1.48^{\mathrm{gh}}$ & $175.71^{\mathrm{a}}$ & $216.53^{\text {de }}$ \\
\hline F5110005-13-5 & $14.54^{\mathrm{b}}$ & $5.01^{\mathrm{a}-\mathrm{d}}$ & $14.34^{\mathrm{abc}}$ & $8.46^{\mathrm{cb}}$ & $59.23^{\text {efg }}$ & $442.00^{\mathrm{ab}}$ \\
\hline F5110005-13-12 & $14.32^{\mathrm{b}}$ & $4.73^{\mathrm{a}-\mathrm{e}}$ & $9.03^{\mathrm{def}}$ & $5.72^{\mathrm{c}-\mathrm{f}}$ & $75.41^{\mathrm{c}-\mathrm{f}}$ & $375.71^{\mathrm{abc}}$ \\
\hline F5120005-11-1 & $12.34^{\mathrm{bcd}}$ & $4.25^{\mathrm{b}-\mathrm{f}}$ & $11.81^{\mathrm{b}-\mathrm{f}}$ & $7.20^{\mathrm{b}-\mathrm{e}}$ & $54.38^{\mathrm{fg}}$ & $351.51^{\mathrm{a}-\mathrm{d}}$ \\
\hline F8002005-12-1 & $13.11^{\mathrm{bc}}$ & $4.89^{\mathrm{a}-\mathrm{d}}$ & $10.64^{\mathrm{c}-\mathrm{f}}$ & $5.13^{\text {def }}$ & $78.22^{\mathrm{c}-\mathrm{f}}$ & $322.90^{\mathrm{bcd}}$ \\
\hline
\end{tabular}

Keterangan : $\quad \sigma_{\mathrm{g}}^{2}=$ ragam genetik, $\sigma_{\mathrm{e}}^{2}=$ ragam lingkungan, $\sigma_{\mathrm{gxe}}^{2}=$ ragam interaksi, $\sigma_{\mathrm{p}}^{2}=$ ragam fenotipe, $\mathrm{KKG}=$ koefisien keragaman genetik, $\mathrm{h}_{\mathrm{bs}}^{2}=$ heritabilitas arti luas, $\mathrm{UB}=$ umur berbunga, $\mathrm{UP}=$ umur panen, $\mathrm{TT}=$ tinggi tanaman, $\mathrm{TD}=$ tinggi dikotomus, $\mathrm{LT}=$ lebar tajuk, $\mathrm{PB}=$ panjang buah, $\mathrm{PTB}=$ panjang tangkai buah, $\mathrm{DB}=$ diameter buah, $\mathrm{BB}=$ bobot per buah, $\mathrm{JBT}=$ jumlah buah pertanaman, dan BBT = bobot buah per tanaman. 
dengan ketidakkemiripan (similarity) sebesar 10 satuan seperti pada Gambar 3. Kelompok I terdiri atas genotipe C51, C105, C111, C117, C118, C157 dan C159. Kelompok II terdiri atas genotipe $\mathrm{C} 2, \mathrm{C} 19, \mathrm{C} 140$, F5 $11 \times 5$ 13-5, F5 $11 \times 5$ 13-12, F5 12×5 11-1 dan F8 2×5 12-1. Kelompok III hanya terdiri atas $\mathrm{C} 18$. Selanjutnya kelompok IV terdiri atas C145 dan C160. Sementara itu kelompok V, VI dan VII juga hanya terdiri atas C2, C143 dan C120 (Gambar 2).
Kelompok yang terbentuk mencerminkan tipe tetua (cabai) yang digunakan. Kelompok I mewakili tipe cabai keriting pendek, kelompok II mewakili tipe cabai semi keriting, kelompok III, V dan VI mewakili tipe cabai besar dengan ukuran spesifik, kelompok IV mewakili tipe cabai rawit dan kelompok VII mewakili tipe cabai keriting panjang. Pengelompokan genotipe dengan menggunakan analisis gerombol ini diharapkan dapat membantu pemilihan tetua

Tabel 5. Nilai duga komponen ragam dan heritabilitas dari 20 genotipe tanaman cabai pada dua lokasi

\begin{tabular}{|c|c|c|c|c|c|c|c|c|}
\hline \multirow{2}{*}{ Karakter } & \multicolumn{8}{|c|}{ Komponen ragam dan heritabilitas } \\
\hline & $\sigma_{g}^{2}$ & $\sigma_{e}^{2}$ & $\sigma_{g x e}^{2}$ & $\sigma_{p}^{2}$ & KKG & Kriteria & $\mathbf{h}^{2}{ }_{b s}$ & Kriteria \\
\hline$\overline{\mathrm{UB}}$ & 30.55 & 23.58 & 27.89 & 48.42 & 10.75 & sempit & 0.63 & Tinggi \\
\hline UP & 3.77 & 2.15 & 0.00 & 4.13 & 2.11 & luas & 0.91 & Tinggi \\
\hline TT & 60.94 & 93.39 & 48.54 & 100.77 & 12.16 & sempit & 0.60 & Tinggi \\
\hline TD & 11.48 & 9.29 & 4.53 & 15.29 & 12.29 & luas & 0.75 & Tinggi \\
\hline LT & 38.98 & 37.48 & 21.1 & 55.78 & 7.79 & luas & 0.70 & Tinggi \\
\hline PB & 9.13 & 3.7 & 2.24 & 10.86 & 24.42 & luas & 0.84 & Tinggi \\
\hline РTB & 0.39 & 0.28 & 0.12 & 0.5 & 14.34 & luas & 0.78 & Tinggi \\
\hline DB & 11.07 & 3.46 & 3.67 & 13.48 & 29.59 & luas & 0.82 & Tinggi \\
\hline BB & 11.78 & 1.68 & 1.21 & 12.67 & 61.76 & luas & 0.93 & Tinggi \\
\hline JBT & 1314.88 & 373.47 & 11.35 & 1382.8 & 44.46 & luas & 0.95 & Tinggi \\
\hline BBT & 6336.64 & 3943.45 & 1821.96 & 7904.86 & 26.41 & luas & 0.80 & Tinggi \\
\hline
\end{tabular}

Keterangan: Angka yang diikuti huruf yang sama pada kolom yang sama tidak berbeda nyata menurut DMRT taraf 5\%

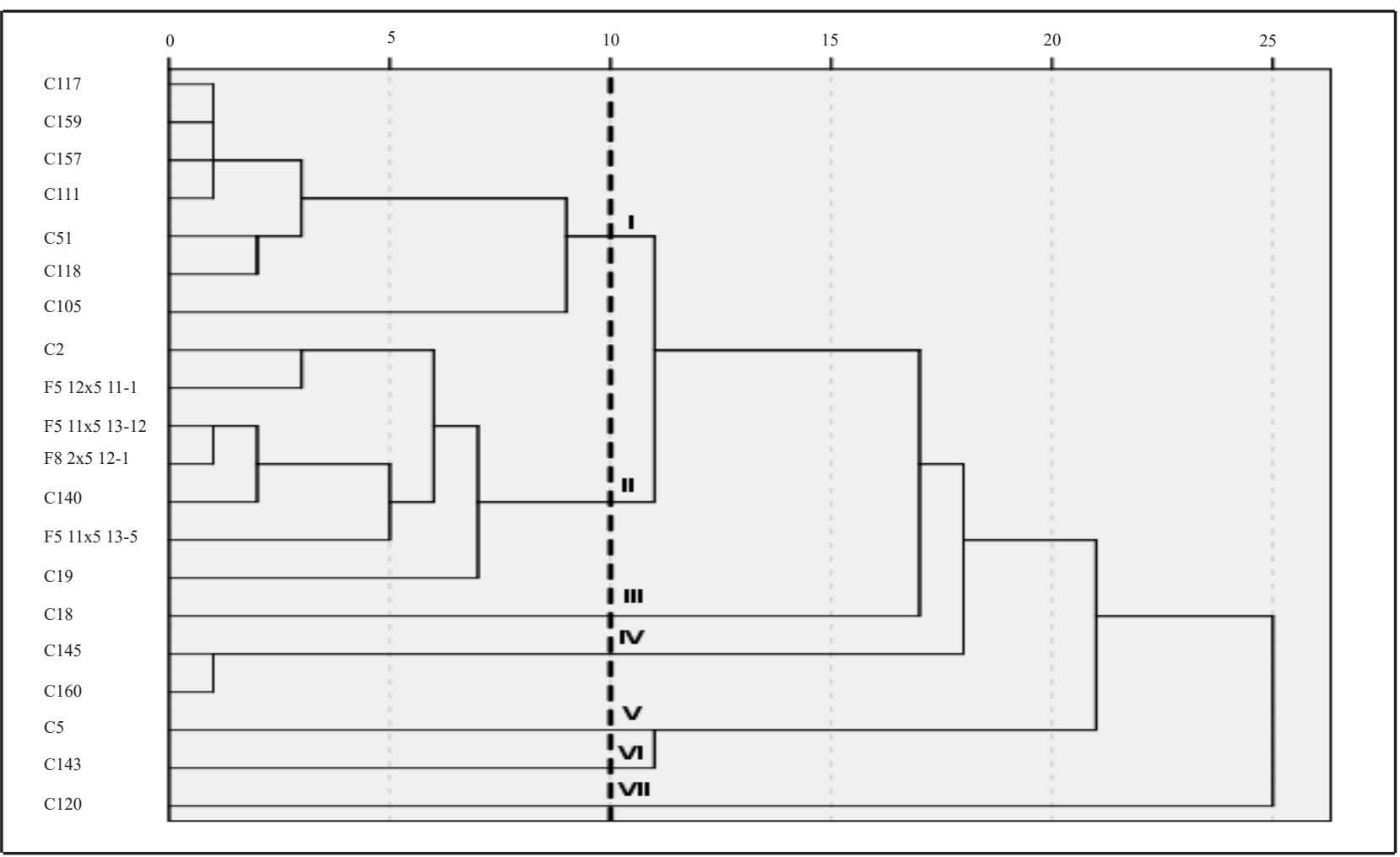

Gambar 2. Dendrogram hasil analisis gerombol 20 genotipe cabai 
dalam kegiatan yang akan dilakukan selanjutnya yaitu untuk merakit varietas cabai unggul baru dengan ukuran buah tertentu.

\section{KESIMPULAN}

Interaksi genetik lingkungan berpengaruh sangat nyata pada karakter yang diamati, kecuali umur panen dan jumlah buah per tanaman. Umumnya penampilan karakter bobot buah per tanaman pada lokasi penanaman di Rimbo Panjang memperlihatkan respon yang lebih baik daripada lokasi penanaman Leuwikopo. Karakter yang diamati umumnya memiliki nilai koefisien keragam genetik kriteria luas. Nilai heritabilitas arti luas setiap karakter yang diamati memiliki kriteria tinggi.Analisis gerombol yang dilakukan telah mengelompokkan 20 genotipe menjadi 7 kelompok.

\section{UCAPAN TERIMA KASIH}

Terima kasih disampaikan kepada Direktorat Pendidikan Tinggi, Kementerian Pendidikan dan Kebudayaan Republik Indonesia yang telah membiayai penelitian ini melalui Hibah PEKERTI pada Tahun 2012.

\section{DAFTAR PUSTAKA}

Baihaki, A. 2000. Teknik Rancang dan Analisis Penelitian Pemuliaan (Diktat Kuliah). Fakultas Pertanian Universitas Padjadjaran. Bandung.

[BPS] Badan Pusat Statistik. 2011. Luas Panen, Produksi dan Produktivitas Cabai, 2009-2011. http://www.bps. go.id/. [10 September 2012].

Elrod, S.L., W.D. Stansfield. 2002. Schaum's Outline of Theory and Problems of Genetics, 4th ed.(pp. 43-45). New York (US): McGraw-Hill.

Geleta, F.L., T.M. Labuschagne. 2006. Combining ability and heritability for vitamin $\mathrm{C}$ and total soluble solids in pepper (Capsicum annuum L.). J Sci Food Agric. 86(9):1317-1320.

Hallauer, A.R., J.B. Miranda. 1995. Quantitative Genetics in Maize Breeding2 ${ }^{\text {nd }}$ edition. Iowa (US): Iowa State Univ Press.

[IPGRI] International Plant Genetic Resources Institute. 1995. Descriptors for Capsicum (Capsicum spp.). Italia. $51 \mathrm{p}$.

Kementerian Pertanian RI. 2012. Komsumsi perkapita sayuran di Indonesia periode 2011. http://aplikasi. deptan.go.id/ [diunduh 2012 Sept 10].
Marame, F., L. Desalegne, S. Harjit, C. Fininsa, R. Sgvald. 2008. Genetic components and heritability of yield and yiled related traits in hot pepper. Res. J. Agric Biol. Sci. 4:803-809.

Mattjik, A.A., I.M. Sumertajaya. 2011. Sidik Peubah Ganda dengan Menggunakan SAS. Bogor (ID): IPB Pr.

Mishra, A.C.M., S.V. Singh, H.H. Ram. 2004. Studies on genetic variability in capsicum (Capsicum annuum L.) under mid hills of Uttaranchal. Capsicum Eggplant News. 23:41-44.

Orobiyi, A., A. Dansi, P. Assogba, L.Y. Loko, M. Dansi, R. Vodouhe, A. Akouegninou, A. Sanni. 2013. Chili (Capsicum annuum L.) in southern Benin: production constraints, varietal diversity, preference criteria and participatory evaluation. Int. Res. J. Agric. Soi. Sci. 3(4):107-120.

Pinaria, A., A. Baihaki, R. Setiamihardja, A.A. Daradjat. 1995. Variabilitas genetik dan heritabilitas karakterkarakter biomassa 53 genotipe kedelai. Zuriat 6(2):88-92.

Poehlman, J.M., D.A. Sleeper. 1995. Breeding Field Crops. Fourth Edition. Iowa (US): Iowa State University Pr.

Roy, D. 2000. Plant Breeding, Analysis and Exploitation of Variation. New delhi (IN): Narosa Publishing House.

Sreelathakumary, I., L. Rajamony. 2004. Variability, heritability and genetic parameters of hot pepper (Capsicum annuum L.). J. Trop Agric. 42:35-37.

Syukur, M., S. Sujiprihati, R. Yunianti, D.A. Kusumah. 2010. Yield Evaluation of Pepper Hybrids and Their adaption at Four Location in Two Years. J Agron Indonesia. 38(1):43-51.

Syukur, M., S. Sujiprihati, R. Yunianti. 2012. Teknik Pemuliaan Tanaman. Penebar Swadaya. Jakarta.

Tembhume, B.V., S.K. Rao. 2012. Heterosis and Combining Ability in CMS Based Hybrid Chilli (Capsicum annuum L.). J Agric Sci. 4(10).

Yunianti R, S. Sastrosumarjo, S. Sujiprihati, M. Surahman, S.H. Hidayat. 2011. Diallel analysis of chilli (Capsicum annuum L.) resistance to Phytophthora capsici Leonian. J Agron Indonesia. 39(3):168-172. 